УДК $811.161 .2 ' 27$

Л. А. Білоконенко

\title{
ЛІНГВІСТИЧНІ ОЗНАКИ І ЗАСОБИ ВИРАЖЕННЯ КОНФЛІКТУ СУБ'СКТИВНОГО ХАРАКТЕРУ
}

Білоконенко Л. А. Лінгвістичні ознаки і засоби вираження конфлікту суб'єктивного характеру.

У статті описано маркери мовної репрезентації міжособистісного конфлікту суб’єктивного характеру, мовні форми і засоби реалізації конфлікту на базі реагувань особи, обгрунтовано зв'язок розвитку конфліктів з переживаннями і почуттями людини, виявлено українські лінгвокультурні причини політичних конфліктів. 
Ключові слова: міжособистісний конфлікт суб'єктивного характеру, засоби вираження конфлікту, лінгвістичні ознаки конфлікту, політичний конфлікт. характера.

Белоконенко Л. А. Лингвистические признаки и средства выражения конфликта субъективного

В статье описаны маркеры речевой репрезентации межличностного конфликта субъективного характера, языковые формы и средства реализации конфликта на основе реакций личности, обоснованно связь развития конфликтов с переживаниями и чувствами человека, определены украинские лингвокультурные причины политических конфликтов.

Ключевые слова: межличностный конфликт субъективного характера, средства выражения конфликта, лингвистические признаки конфликта, политический конфликт.

Bilokonenko L. A. Linguistic signs and means of expression in the subjective nature of conflict.

This article describes the representation of verbal markers in interpersonal conflict, based on the reactions of the person and the link between the development of conflicts and feelings of a man were identified, the author also based Ukranian linquistics and cultural causes in political conflicts.

Key words: interpersonal conflict of subjective nature, the linguistic features of the conflict, the means of expression of the conflict, political conflict.

Повсякденність конфлікту не викликає жодного сумніву: існування і розвиток людського суспільства базується на протиріччях та їх подоланні. Через те досить сталою є думка, що конфлікт - це негативне явище деструктивного характеру. Але кожна конфліктна ситуація чи конфлікт мають і свої позитивні наслідки. Можна з упевненістю говорити, що в основі цього феномена - подвійна психологічна природа: він здатний створювати і руйнувати, і не лише міжособистісні стосунки, а й внутрішню природу особи.

Актуальність дослідження визначається тією обставиною, що комунікативна поведінка людини відповідає соціальним (економічним i політичним) факторами, які впливають на психологічний стан особи, ii мовну свідомість. Опис факторів, що обумовлюють мовну поведінку особи в зоні конфлікту, дослідження лінгвістичної, соціальної і психологічної природи мовного конфлікту відноситься до пріоритетного та перспективного напрямку різних галузей знань, але перебуває поки ще на початковій стадії вивчення. При всій різноманітності досліджень ефективної комунікативної поведінки ця проблема ще має значні перспективи для науковців. Необхідність вивчення мовної поведінки особи в конфлікті полягає в дослідженні лінгвістичних ознак конфлікту, виявленні засобів його вираження, пов'язаних 3 пошуком шляхів гармонізації взаємодії опонентів, які впливають не лише на міжособистісні стосунки, але й на всю соціальну систему.

Концепція мовного конфлікту, як комунікативного, соціального i культурного явища, обумовленого лінгвістичними та екстралінгвістичними факторами спирається на загальні положення комунікативної лінгвістики, прагмалінгвістки, психолінгвістики, соціолінгвістики, психології конфлікту, лінгвоконфліктології (А. Анцупов, Н. Арутюнова, Р. Барт, М. Блох, Ш. Берн, В. Богданов, Б. Городецький, Р. Грановська, О. Зарецька, О. Земська, К. Ізард, В. Карасик, І. Кобозева, С. Кубрякова, О. Леонтьєв, Н. Муравйова, Н. Пілат, 
Г. Почепцов, І. Сабурова, В. Третьякова, А. Шипілов та ін.). На сьогодні перспективним у лінгвоконфліктології $є$ вивчення лінгвістичних ознак і засобів вираження міжособистісного конфлікту. Мета нашого дослідження - описати лінгвістичні ознаки і засоби вираження міжособистісного конфлікту суб'єктивного характеру, для чого маємо виявити мовні форми і засоби репрезентації конфлікту на базі реагувань особи.

Ілюстративною базою дослідження міжособистісних конфліктів суб'єктивного характеру є мовний матеріал, який зафіксовано у суспільнополітичних та аналітично-дискусійних програмах: «Про головне» (канал УT-1), «Шустер Live» (канал УТ-1), «Свобода слова» (канал ICTV), «Плюс - мінус» (Перший Національний), «Час. Важливо» (5 канал), «Сьогодні. Про головне» (ТВI). Час фіксації: вересень - листопад 2011 року. Визначено, що це конфлікти низької інтенсивності, нетривалі, які виявляють протиріччя опонентів у мотивах, потребах, ціннісних орієнтаціях, переконаннях, оцінках суспільно-політичних проблем в Україні. Учасники - політики, депутати, політичні експерти, урядовці, які різняться за віком, освітою, професійним і життєвим досвідом, політичними поглядами, цілями і завданнями, статусом. Унаслідок цих відмінностей виникають конфліктні ситуації і конфлікти. Це особи, які знаходяться в полі політичного конфлікту, де відбувається зіткнення різних соціально-політичних сил, суб'єктів політики в їх прагненні реалізувати свої інтереси і цілі, пов'язані з боротьбою за владу, іiі перерозподілом, зміною свого політичного статусу, політичними перспективами партії, блоку тощо.

Теорія політичного конфлікту активно розвивається в XX ст. Визнаним теоретиком конфлікту є Г. Зіммель, якому належить ідея про конфлікт як фактор, що сприяє зближенню й об'єднанню людей. А. Смолл розглядає конфлікт як основний суспільний процес, який спричиняє соціалізацію суспільства. Л. Козер і Р. Дарендорф говорять про універсальність конфліктів та їхню позитивну роль у суспільстві. Психолог М. Дойч зазначає, що «наукова проблема конфлікту полягає в можливості відповісти на запитання: за яких умов швидше виникає жива полеміка, ніж смертельна суперечка», він пише, що «необхідно аналізувати поведінку особи, iї бажання вирішити проблему, ураховуючи соціокультурний контекст» [3, с. 174]. Психолог Н. Гришина звертає увагу на подвійну психологічну природу конфлікту, вважаючи, що він має позитивні наслідки, є джерелом розвитку всіх здібностей особи, стимулює іiі до активності, є сигналом до змін в усіх сферах життя людини [2, с. 70]. Безперечно, конфлікт стає джерелом самоствердження особистості, іiі соціалізації. По відношенню до соціуму конструктивним конфлікт $\epsilon$ тому, що він виступає як засіб активізації соціального життя суспільства, висвітлює невирішені проблеми в його діяльності [6, с. 74]. 
Дія розвитку конфлікту базується на 4 групах факторів і причинах: об'єктивних, організаційних, соціально-психологічних і особистісних [1, c. 231]. Перші дві групи мають об'єктивний характер, третя та четверта - суб'єктивний. До об'єктивних причин відносять обставини соціальної взаємодії людей, які призводять до зіткнення інтересів, поглядів, установок. Соціально-економічні умови сучасного життя формують нестійку до конфлікту особистість, яка захищає власні інтереси, спрямована на владу, силу, авторитет і досить часто діє психологічно невмотивовано. В основі конструктивних конфліктів 3 позитивними i негативними наслідками знаходяться об'єктивні причини. А от в основі деструктивних, які мають лише негативні наслідки, - суб'єктивні причини: соціально-психологічні й особистісні [4, с. 27]. Кожен конфлікт має об'єктивний і суб'єктивний характер. Але наявність об'єктивних причин не $є$ обов'язковою для прояву суб'єктивних. Окрім того, суб'єктивний конфлікт посилюється і тими мовними формами його реалізації на базі реагувань людини, що провокують його розвиток та ескалацію.

Конфлікт має «людське обличчя»: особа не просто здатна до участі в ньому, вона має свідомість, волю, активність до конфліктних дій, але людина має і вибір. Конфліктогени, виражені мовними одиницями різних рівнів, служать комунікативними маркерами конфліктності чи толерантності людини. Лінгвістична природа конфлікту зумовлена адекватністю чи неадекватністю взаєморозуміння комунікантів, знанням чи незнанням норм мови, рівнем сприйняття і декодування конфліктогенів у спілкуванні, а також тим, що конфлікт має культурні й етнічні форми прояву і сприйняття, які теж закріплені в мові [5, с. 87]. Безперечно, правильне трактування мови конфлікту сприяє вихованню соціальної толерантності особистості.

Лінгвістичними маркерами міжособистісних конфліктів найчастіше бувають певні лексеми, які характеризують внутрішні складові конфлікту, описують його зовнішні прояви за допомогою додаткової інформації аксіологічного, емотивного й образно-експресивного значення. Експлікаторами таких станів виступають лексичні повтори, оцінна лексика, заперечення, опис власного психоемоційного стану (тривога, невдоволення собою, роздратування, сумнів, відчай, збентеження, сором тощо). Умовою успіху в розпізнаванні конфліктного маркера в політичному конфлікті $\epsilon$ загальний контекст, хоч значна їх частина трактується однозначно і без контексту.

Промова міністра соціальної політики С. Тігіпка щодо суспільнополітичних проблем країни (державні стандарти життя, споживчий кошик, позики у МВФ, ціна на газ, податок на багатство, пенсійне забезпечення чорнобильців) включає конфліктні маркери, за допомогою яких він реагує на певні «незручні» питання, пояснює свою позицію як урядовця, виявляє ставлення до опонентів: жертви, зрада, вводити в оману, безглузда політика попередників, чехарда, лукавство. Але міністр використовує 
конфліктогени коректно, стримано реагує на «провокації» опонентів, не виявляє власний психоемоційний стан. Що не можна сказати про лідера ВО «Свобода» О. Тягнибока. В ефірі «Шустер Live» політик активно використовує оцінну й інвективну лексику: маячня, брехливі реакиії, маразм, спекуляція, лукавство, абсолютна брехня, лицемірство, бездарності, брехливі слова, бездарний і непрофесійний уряд, видавили (опозицію), розсілися, розкрадав кошти. Легко демонструє, але i контролює, власний психоемоційний стан (роздратування, гнів, сором за опонентів), що реалізується у вмінні послуговуватися силою голосу, темпом, логічними паузами. Голова політичної партії «За Україну!» В. Кириленко в тій же студії вступив у міжособистісний конфлікт 3 представником Партії регіонів О. Сфремовим, не стримуючи емоції й особливо не добираючи слова: красиво обіияли $i$ збрехали, не нав'язуйте свою волю, «типу» лишається українська мова, «типу» команда технократів. А от заступник голови партії «Батьківщина» О. Турчинов у конфліктній взаємодії надає перевагу запереченням: ия влада не здатна, не вбивайте людей, не робіть цуього, цее не ваша справа, у циих питаннях вони не розбираються, нас не чують; максимально уникаючи лексем 3 негативно-оцінним значенням (зафіксовано лише брехливий уряд, влада банкрутів), ніби підкреслюючи свою перевагу, небажання характеризувати інтелектуальні чи моральні якості опонентів. Політик акцентує увагу на неприпустимості дій влади, завдяки чому він намагається заручитися підтримкою глядачів. Народний депутат В. Зубанов («Партія регіонів») під час ефіру у студії ТВІ теж поводився дуже стримано і дозволив собі лише дві фрази конфліктного спрямування: Це дурня! і Це провокація! Він впливав на опонента за допомогою переконання. Це м'яка тактика, яка не передбачає мовної агресії, що і було продемонстровано. Тактика апеляції до розуму, логіки опонента, яку часто обирає в конфліктному спілкуванні А. Яценюк (голова партії «Фронт змін»), також не дозволяє йому вдаватися до явно конфліктної лексики. Політик представляє себе опонентам i суспільству як компромісну політичну фігуру, тому демонструє вміння толерантно ставитися до співрозмовника, контролює мовлення й емоції. Конфліктогенами стали деякі дієслова, які характеризують дії влади: дотиснути (опозицію), знову проскочити (у Верховну Раду), розсілися (про депутатів), хочуть покерувати, лукавлять, «рятують» краӥну. Депутат І. Богословська активно бере участь у телевізійних політичних програмах, де звертає на себе увагу категоричністю суджень. Вона не оминає оцінну лексику (шантаж, брешете, брехливі заклики, продажна опозиція, бездарні рімення), але глядачів більше шокує пї жорстка наступальна тактика по відношенню до опонентів. Політик не боїться демонструвати свій психоемоційний стан байдужості до співрозмовника, який підкреслюється іронічною посмішкою, що $є$ ознакою жорсткої тактики морального тиску. 
Тож більшість політиків не нехтують використанням конфліктної лексики. Продуктивно використовуються конфліктні маркери, які визначають недоброзичливу, недружню, навіть ворожу оцінку опонентів. Активно віддають перевагу лексиці, яка оцінює інтелектуальні, моральні, ділові якості опонентів, доводячи, що будь-яка стратегія і тактика в досягненні мети для них прийнятна.

Крім вербальних засобів, міжособистісні конфлікти виявляються і паралінгвістичними засобами, до яких відносяться голосові елементи невербального коду, замовчування, паузи, візуально-слухові невідповідності, фізіологічні реакції людини (почервоніння обличчя, вух; різкі рухи тіла, переривчасте дихання тощо). Так депутат К. Куликов (НУНC) під час промови опонента роздивлявся свої руки і стіл, демонструючи байдужість до слів опонента; схрещував на грудях руки, що є оборонним жестом, яким реагують на загрозу і конфліктні ситуації. Коли почав говорити, робив енергійні, різкі рухи рукою, високо піднімав відкриті долоні рук, показував руками певний напрям, підкріплюючи цим свої слова Це були жести знервованості, які використовують люди, які «граються» 3 партнерами, не «розкривають карти», або демонструють заклопотаність 3 приводу певного питання. Політик підтверджував свій емоційний стан і перериванням опонента. А саме переривання комунікації, нещирість, «гра», контроль за виразом обличчя є маркерами конфліктної взаємодії. Експресія тіла К. Куликова вимагала від його опонента депутата В. Зубанова осмислення конфлікту та залучення власного життєвого досвіду міжособистісних стосунків задля інтерпретації мови співрозмовника. Треба зазначити, що сам В. Зубанов контролював свої емоції і мовлення, не відволікався від теми, не реагував на конфліктогени.

Замовчуванням i паузами як паралінгвістичними засобами міжособистісних конфліктів активно послуговувався С. Тігіпко, відповідаючи на запитання щодо економічної ситуації в країні. Певні факти було складно озвучувати, але відповідати опоненту необхідно, тому Міністр, як розважливий політик, потребував часу для формулювання відповіді (Це трошки (пауза) впливає на стосунки з Росією). Інколи паузи було доповнено повторами запитання (Чому? (пауза) Чому ми маємо так зробити? (пауза) Це складне запитання!; Чому? (пауза) Тому що...) або повторами слів і виразів, які містилися у формулюванні (запитання: Bu 3 ним особисто спілкуєтеся? Отримуєте добро на всі реформи?; відповідь: Регулярно спілкуємося, (пауза) отримую добро; запитання: Подорожчання газу для населення поки що не планується?; відповідь: Подорожчання газу для населення поки щьо не планується, (пауза) ми все робимо для ц̧ього).

Лінгвістичний аспект міжособистісних суб'єктивних конфліктів необхідно пов'язувати і 3 переживаннями та почуттями людини. Конфлікти, викликані цими аспектами, характеризуються переоцінкою цінностей опонентів. Експлікаторами таких переживань виступають 
порівняння і протиставлення, заперечення, синтаксичні повтори; окличні і питальні речення, зокрема риторичні, для вираження емоційного стану; хаотичність мовлення. Найактивніше учасники програм ставлять запитання один одному i, не чекаючи реакції іншої сторони, самі на них відповідають. Наприклад, О. Тягнибок: Для чого Ви вводите людей в оману? Що Ви вигадуєте? Ви створюєте провокацію; В. Кириленко: Ви робите изе свідомо? Так! або Як доконали украӥнську мову? Я розкажу як; К. Куликов: Немає грошей? Я розкажу, як ӥх немає; О. Сфремов: Вони для Вас провокатори? Це дурня; О. Голуб: Хто знищчи українські бібліотеки, кіностудї, видавництва? Ви; О. Тягнибок: А чому така реакція світу на арешт екс-прем'єра Тимошенко? Чому зразу дали реакцію американиі, європейці? A знаєте чому? А вся проблема в тому, щзо..; $A$ от в Грузії такого не могло би бути. Чому? Та вони...; А. Яценюк: Чому опозиція без Тимошенко неможлива? А я скажу вам чому. По-перше...; О. Мороз: Чому ви не виводите людей на майдан? Чому люди самі не йдуть на майдан? Тому щзо...; І. Богословська: Треба вважати Тимошенко святою? Та вона порушила всі закони. Ці запитання в конфліктній взаємодії не мають за мету відшукати істину. Вони виділяють чи підкреслюють певну фразу, думку; мають умовний характер, навіть в інтонації. Це є твердження учасника програми, лише висловлене в питальній формі.

Задля пояснення власних переживань і почуттів учасники телевізійних програм використовують у комплексі 3 оцінною лексикою структури 3 порівняннями, протиставленнями, запереченнями, синтаксичними повторами: С. Тігіпко: У нас такого не було!; Ніякої доброї волі, буде, як треба; К. Куликов: Нi! Це не так!; О. Голуб: Не треба істерики! Мене не треба вчити!; В. Кириленко: Ви щось переплутали. Не можна говорити про це; О. Турчинов: Але ж головне, жодної провини, жодного, я підкреслюю, порушеного закону Тимошенко не зробила; Вони не хочуть, щзоб ми ие обговорювали; Зараз Богословська розкаже, щуо було 15 років тому, а ми з вами будемо сперечатися - ні, 15 років тому було щзось інше; І. Богословська: Олександр Володимирович зараз вам говорить неправду, або тому щзо він не розбирається, або тому щуо відверто бреше; О. Мороз: Послухайте. Я закінчу. Я закінчу. Почекайте; А. Яценюк: A знаєте, скільки коштує вся українська армія? У два рази менше, ніж вся правоохоронна система. Та правоохоронна система, яка...; А десятки людей, десятки людей, яких...; Вирок Тимошенко - це спроба... Це спроба знищчити опозицію.

Необхідно говорити і про лінгвокультурні причини міжособистісних конфліктів суб'єктивного характеру, якими є, у першу чергу, особливості громадсько-політичної діяльності опонентів, а також зіткнення їхніх політичних установок, гендерні прояви, порушення етичних ідеалів тощо. Конфліктними маркерами виступають: сумніви у словах співрозмовника, нещирість у комунікації, представлення власних схем спілкування, опис внутрішнього стану, хвилювання, перепади настрою, демонстративний 
подив, явна агресія. Умовою успіху в розпізнаванні мовних засобів вираження цих конфліктів $є$ загальний контекст i знання глядачів про національний ментальний комплекс. Саме ментальні риси українців (певний консерватизм, зваженість, уповільненість у прийнятті рішень, підозрілість та ін.) стають не лише специфічним «регулятором» економічних i політичних подій у країні, але i впливають на перебіг політичного конфлікту. Через це політики змушені дещо гіперболізувати свої почуття, емоції; вдаватися до прийомів, які підвищують увагу глядачів, змушують робити потрібні висновки, швидше реагувати на слова. Маркерами виступають лексичні компоненти, конструкції з порівнянням, протиставленням, запереченням, структури з умовним компонентом.

У своїй промові С. Тігіпко часто апелює до логіки, філософських законів буття, говорить про соціальну справедливість (3a логікою, за філософією багаті повинні ділитися з бідними; Я вважаю, щуо ие соціально несправедливо; Дуже маленькі гроші йдуть у Пенсійний фонд; Будемо серйозно розбиратися з організаціями), демонструючи бажання заручитися підтримкою аудиторії. О. Тягнибок апелює до національної гідності глядачів: Україна, товариство, не бідна держава. Україна не бідна держава, в Украӥні просто немає справедливості, повторюючи ключову фразу: Україна не бідна держава. Свідомий українець уважає саме так, тому позитивно реагує на промовця, а промовець, отримавши підтримку аудиторії, має перевагу над опонентом. А. Яценюк «переносить» образ Ю. Тимошенко на Україну: Вирок Тимошенко - це не просто вирок одній особі, изе вирок, який був здійснений по відноменню до Украӥни і українияів, намагаючись викликати чуттєвий відгук, адже наш народ завжди жаліє ображених. Так політик отримує перевагу над опонентом завдяки ментальним почуттям: треба підтримати людину, яку переслідує влада. А от О. Тягнибок вдається до глибших національних складових, згадуючи про релігійні корені українців: Перш за все, я хотів би привітати всіх зі сьогоднішнім святом Пресвятої покрови... і чуючи деякі маячливі речі зі сторони представників влади, мені хотілося б попросити нашу Богородиџюю, яка завжди була покровом для украӥнського народу, для української нації, щцоб вона дала розуму цій франтуватій владі, яка просто знищує украӥнців, знищуе державу... I рішучості хай дасть Богородичя українській нації. Для українців Бог - це внутрішній закон, відповідно до якого треба жити і якому він довіряє себе і своє життя. А тому до людини, яка згадує про Бога, більше довіри. Цей же політик, звертаючись до питання про стосунки 3 Росією (Вони хочуть знищити Україну за вказівкою Кремля), використовує конфліктоген знищити і налаштовує цим глядачів на негативне сприймання іншої країни. Оскільки мова йде про владу, то негативізм переноситься і на неї, адже влада, як говорить політик, до цієї дії причетна. Депутат В. Зубанов торкаєть ще однієї болючої проблеми: розмірковує про непрофесіоналізм влади: Треба до ичих 
питань підходити фахово; Питання треба вивчати досконало, а не говорити про нього. П. Порошенко також характеризує особливості діяльності уряду: $Я$ відповідально стверджую, щуо сьогодні перебування в уряді є надзвичайно ризикованим. Воно вимагає абсолютно жорстких, швидких $і$ професійних кроків, які діючий уряд не демонструє. Громадяни очікують від уряду реальних і позитивних дій, тому, коли політик говорить про непрофесіоналізм влади, він підкреслює невідповідність іiі установок і очікувань людей, що налаштовує їх проти влади та формує для самого політика «групу підтримки». П. Порошенко апелює до такої життєвої цінності, як правда: Вони декларують? Думаю, щзо від декларування до справжньої і щзирої публічної позиції є велика відстань. На жаль, украӥнська політика пронизана брехнею. I ключове, чого не вистачає украӥнській політиці, - правди, украӥнської правди. Саме правда стоїть для українців в основі морального ставлення до іншої людини. Політик упевнений, що треба «жити по правді», керуватися в суспільстві законами совісті і Божими заповідями. Висловлена думка, безперечно, підтримана аудиторією, що стало додатковою перевагою політика у спілкуванні 3 опонентами. Лінгвокультурним експлікатором конфліктів суб'єктивного характеру також виступає бажання змінити неприємну тему. Якщо політик, відповідаючи на запитання, починає говорити про інше (що йому цікаво, що він сам хоче обрати як тему), то направляє хід розмови в потрібному йому руслі, прагне стати лідером спілкування, що позитивно впливає на його психоемоційний стан і захищає від негативних переживань чи почуттів (В. Кириленко: Замість того, щуоб говорити про...давайте згадаємо, щзо...; О. Мороз: Тому я просив би, давайте ми не будемо обговорювати Юлію Тимошенко або когось іншого). Отже, звернення до ментальних традицій, у поєднанні з лінгвістичними засобами вираження конфлікту (багаті повинні, соціально несправедливо, дуже маленькі пенсії, українська політика пронизана брехнею, недемократичні вибори, опозиція жорстко подавлена, подовжують агонію країни, «дохла справа» СЕСУ; не судовий процес, а фарс; недоучена експертиза тощо) надає сторонам перевагу в конфлікті, дозволяє маніпулювати масовою аудиторією.

Особливою лінгвокультурною причиною конфліктів $є$ гендерний прояв. Вітчизняне телебачення зайвий раз доводить, що гендерний дисбаланс у політиці залишається істотним. Не складно помітити, що жіноча політична діяльність, іiі сприйняття глядачем, узаємовідносини 3 політиками-чоловіками $\epsilon$ особливими. Мало того, існує різниця в соціальних оцінках поведінки жінки-політика: вона має бути яскравою особистістю, гідно реагувати на критику, легко орієнтуватися в суспільнополітичному житті держави. Досягнути такого рівня в політичних взаємовідносинах 3 чоловіками нелегко, тому жінки-політики часто «захищаються» жорсткими тактиками в конфлікті. Яскравим прикладом є участь I. Богословської у програмі «Шустер Live» (14.10.2011). Реакції 
політика були яскраві, активні, провокаційні (Шуро, щзо Ви? Перехрестіться, ніколи я не стояла на помаранчевій..., ніколи в житті, не придумуйте). Вона не боїться висловитися різко (Ось дивіться, от дивіться, щзо відбувається - ми підміняємо культуру попсою, ми зміст підмінясмо базіканням. У результаті краӥна стоїть на вухах). Політик сама визнає, що бере участь у конфлікті, а глядачі помічають, що вона із задоволенням грає роль «конфліктної» особистості (Савік... ви з вашої передачі зробили дуже популярну передачу завдяки тому, щуо ви вмієте створити конфлікт. Але це призводить до одурманювання людей...; Не було такого на засіданні Кабінету Міністрів. Ви брешете. Бреше, пан Соболєв). Маркерами конфліктного спілкування I. Богословської виступає недовіра до слів співрозмовника, нав'язування власних тем, демонстративний подив, іронія. Мовними маркерами стали речення 3 порівняннями, протиставленнями, різким запереченням. Депутат не часто використовує питальні речення, надаючи перевагу або простим, неускладненим, стверджувальним реченням з прямим порядком слів; або складним реченням 3 предикативними частинами, які співвідносні 3 простими, неускладненими реченнями (Hi, ми потім розповімо молодим, хто ви, тоді вони зрозуміють, чому ви так себе поводите). Такі речення легко сприймаються, особливо в поєднанні з невербальними засобами.

Отже, лінгвістичними ознаками i засобами вираження міжособистісного конфлікту суб'єктивного характеру в мовленні українських політиків, урядовців виступають лексичні повтори, оцінна лексика, заперечення, опис власного психоемоційного стану. Продуктивно використовуються маркери, які визначають недоброзичливу, недружню, ворожу оцінку опонентів. У політичному конфлікті віддається перевага лексиці, яка оцінює інтелектуальні, моральні, ділові якості опонентів. Більшість аксіологічних лексем $є$ іменниками або прикметниками. Визначено і паралінгвістичні складові політичних конфліктів: елементи невербального коду, замовчування, паузи, фізіологічні реакції. Лінгвістичний аспект міжособистісних суб'єктивних конфліктів пов'язуємо i $з$ переживаннями та почуттями учасників програм. Експлікаторами таких переживань виступають порівняння, протиставлення, заперечення, синтаксичні повтори, окличні і питальні речення. Найактивніше опоненти використовують питальні речення, які підкреслюють певну фразу, думку, але мають умовний характер. Лінгвокультурні особливості конфліктів обумовлені зіткненням i протиборством культурно специфічних стереотипів і установок. У своїх промовах політики апелюють до логіки, філософії, говорять про соціальну справедливість, національну гідність, згадують про релігію, розмірковують про несправедливість влади. Особливою лінгвокультурною причиною конфліктів $є$ гендерний прояв. Участь у політичних конфліктах з чоловіками вимагає від жінок-політиків 
жорстких психологічних тактик i активного використання конфліктних лінгвістичних засобів.

На сучасному етапі в Україні існує тенденція перекладати всю відповідальність за долю нації на владу. Учасники політичних шоу, розуміючи цю тенденцію, не аналізують свої прорахунки, а шукають винного в таборі опонентів. Така нерозбірливість у виборі конфліктної тактики, активність до конфліктних дій $є$ ознакою негармонійної комунікації. Шкода, що наші державні мужі не згадують чи не знають слова Демокрита: «Правитель, який володарює над іншими, повинен, насамперед, навчитися володарювати над самим собою».

\section{Література}

1. Анцупов А. Я. Конфликтология : [учебник для вузов] / А. Я. Анцупов, А. И. Шипилов. - М. : ЮНИТИ - Дана, 2001. - 591 с.

2. Гришина Н. В. Психология конфликта / Н. В. Гришина. - СПб : ПИТЕР, 2005. - 464 с.

3. Дойч М. Конструктивное разрешение конфликта : принципы, обучение и исследования / М. Дойч // Психология конфликта. - СПб. : Питер, 2001. - С. 173-198.

4. Емельянов С. М. Практикум по конфликтологии / С. М. Емельянов. - СПб. : Питер, 2004 с.

5. Муравьева Н. В. Язык конфликта / Н. В. Муравьева. - М. : Термика, 2004. - 214 с.

6. Орлянський В. С. Конфліктологія : [навч. посібн.] / В. С. Орлянський. - К. : Центр учбової літератури, 2007. - $160 \mathrm{c}$.

Стаття надійшла до редакції 21.10.2011 р. 